\title{
CONFRONTATION AND THE HEARSAY RULE
}

In 1953, the Supreme Court refused to reverse the state conviction of a defendant who had been incriminated by the confessions of his co-defendants and was unable, at their joint trial, to cross-examine the confessors." "Basically ... [the defendant's] objection to the introduction of the confessions is that as to him they are hearsay. The hearsay-evidence rule, with all its subtleties, anomalies and ramifications, will not be read into the Fourteenth Amendment."2 In 1965, however, in an opinion of breathtaking simplicity, the Court all but transformed its argument by horrible consequence into constitutional reality. In Pointer v. Texas ${ }^{3}$ the Court read into the Fourteenth Amendment the confrontation clause of the Sixth Amendment, ${ }^{4}$ making no attempt to distinguish that clause from the evidentiary rule against hearsay. ${ }^{5}$

Petitioner in Pointer and a co-defendant had been arrested for robbery and identified by the victim at a preliminary hearing where neither defendant was represented by counsel. ${ }^{\circ}$ After the prosecutor

1. Stein v. New York, 346 U.S. 156 (1953), overruled on other grounds, Jackson v. Denno, 378 U.S. 368 (1964).

2. 346 U.S. at 196.

3. 380 U.S. 400, overruling West v. Louisiana, 194 U.S. 258 (1904).

4. "In all criminal prosecutions, the accused shall enjoy the right . . . to be confronted with the witnesses against him ...."

5. With the caveat that "simplification is falsification," McCormick offers the following definition of hearsay: "Hearsay evidence is testimony in court or written evidence, of a statement made out of court, such statement being offered as an assertion to show the truth of matters asserted therein, and thus resting for its value upon the credibility of the out-of-court asserter." MCCoRMICK, Evidence \& 225 (1954). See also, 5 Wigmonz, EVIDENCE § 1361; 6 id. § 1766 (3d ed. 1940); Morgan, Hearsay Dangers and Application of the Hearsay Concept, 62 HARv. L. Rev. 177 (1948).

6. Right to counsel seems to have beckoned as an alternative, and innocuous, ground of decision, but the Court found that problem more difficult than the one it ultinately faced. The Court had interpreted Gideon v. Wainwright, 372 U.S. 335 (1963), to require that counsel be provided at any critical stage of a criminal proceeding, including the preliminary hearing. White v. Maryland, 373 U.S. 59 (1963). Cf. Hamilton v. Alabama 368 U.S. 52 (1961). But the Court distinguished those cases as having dealt with preliminary hearings that could have been the occasion for entering a plea; the Texas hearing could not. 380 U.S. at 402 . The Court expressly refused to decide whether there might be other features of the Texas hearing so critical as to make counsel compulsory, implying that the record was not sufficiently informative. 380 U.S. at 403 . But the record did show, at a minimum, that prosecution testimony could be taken at the Texas prelim. 
showed at the trial that the victim had left the state, he sought to introduce a transcript of the testimony the victim gave at the preliminary hearing. The defense attorney objected, claiming his client had been denied " confrontment of the witnessess ...," "7 a contention rejected by the trial and appellate courts. Reversing, the Supreme Court observed that the right to cross-examine witnesses is included in the Sixth Amendment right to confront them, and then incorporated the federal confrontation standard into the Fourteenth Amendment.

With that stroke, the Court imposed on the states a doctrine of uncertain reach. It did not elaborate past exegesis of the clause, which has casually identified confrontation with the irreducible core of the hearsay rule. ${ }^{8}$ The Court in Pointer, without mentioning hearsay, recognized two exceptions to the rule against hearsay as exceptions to the Sixth Amendment's confrontation requirement. ${ }^{9}$ Thus Pointer

inary hearing and preserved for later use at the trial. If the Court felt unable to hold flatly that counsel was required at the Texas hearing, it might simply have ruled that counsel was required at any hearing whose testimony was to be preserred for later trial. Inasmuch as prosecutors could never be sure that every witness who testified at a preliminary hearing would be able to appear at the trial, they would probably wish to guarantee that testimony could be preserved for Iater use by obtaining counsel for defendants at all preliminary hearings. Still, such a rule of cavcat prosecutor would not have demanded a finding that the Texas preliminary hearing was by its very nature a critical stage at which counsel was required.

7. 380 U.S. at 401.

8. See, e.g., Snyder v. Massachusetts, 291 U.S. 97, 107 (1934) (Cardozo, J.):

Nor has the privilege of confrontation at any time been without recognized exceptions, as for instance dying declarations or documentary evidence. [Citation of cases omitted.] The exceptions are not even static, but may be enlanged from time to time if there is no material departure from the reason of the general rulc.

Robertson v. Baldwin, 165 U.S. 275, 282 (1897):

Nor does the provision that an accused person shall be confronted with the witnesses against him prevent the admission of dying declarations, or the depositions of witnesses who have died since the former trial.

Compare Kay v. United States, 255 F.2d 476,480 (4th Cir. 1958), cert. denied, 358 U.S. 825 (1958), asserting the clause was

intended to prevent the trial of criminal cases upon affidavits, not to serve as a rigid and inflexible barrier against the orderly development of reasonable and necessary exceptions to the hearsay rule.

9. This Court has recognized the admissibility against an accused of dying declarations, [citation of cases omitted] and of testimony of a decensed witness who has testified at a former trial. [Citation of cases omitted.] Nothing we hold here is to the contrary.

380 U.S. at 407. This passage makes it difficult to interpret the decision as a first step in reassessing the hearsay rule and establishing new standards of rcliability for hearsay exceptions. If any category of admissible hearsay deserves to be climinated as part of such a reassessment, it is the category of dying declarations. See Note 18 infre. Yet the Court offered dying declarations as an example of unquestionably admissible hearsay. 
left undisturbed the notion that the hearsay rule and the constitutional requirement are interchangeable.

Despite the superficial similarity between the evidentiary rule and the constitutional clause, ${ }^{10}$ the Court should not be eager to equate them. Present hearsay law does not merit a permanent niche in the Constitution; indeed, its ripeness for reform is a unifying theme of evidence literature. ${ }^{11}$ From Bentham ${ }^{12}$ to the authors of the Uniform Rules of Evidence, ${ }^{13}$ authorities have agreed that present hearsay law keeps reliable evidence from the courtroom. If Pointer has read into the Constitution a hearsay rule of unknown proportions, reformers must grapple not only with centuries of inertia but with a constitutional prohibition as well.

The major problem is not, however, scraping the barnacles from hearsay law. No hearsay code, however streamlined, could serve np. propriately as a constitutional principle. The goal of any hearsay rule is to admit hearsay when its out-of-court context can serve as an acceptable substitute for cross-examination. ${ }^{14}$ Thus dying declarations are admitted on the theory that a man would not face death with a lie on his lips. ${ }^{15}$ This example illustrates two characteristics of hearsay rules. First, they are at best a partial substitute for cross-examination. Cross-examination helps expose all of the defects of testimony-deficiencies of observation, errors in the use of words, distortions of memory, and deliberate falsification. ${ }^{16}$ Here the out-of-court substi-

10. One writer has suggested that the constitutional right is based on a common law principle which, in turn, finds its origin in a reaction to abuses at the trial of Sir Walter Raleigh. F. H. Heller, The Sixth Amendent 104 (1951). This apparently is the only historical illumination the clause has received.

11. See Weinstein, Probative Force of Hearsay, 46 Iowa L. REv. 331, 344.46 (1961) (collecting epithets).

12. See, e.g., I Bentham, Rationale of Judicial Evidence 449.53 (1827); 3 id. 413.

13. UNIFORM Rule 63(4)(c) holds admissible,

if the declarant is unavailable as a witness, a statement narrating, describing or ex-

plaining an event or condition which the judge finds was made by the declarant at

a time when the matter had been recently perceived by him and while his recollec

tion was clear, and was made in good faith prior to the commencement of the action. National Conference of Commissioners on Unifora State Laws, Handnook 200 (1958). The rule represents on its face a considerable liberalization. But it is weakened by the Commissioners' Note ("Clause (c) is drafted so as to indicate an attitude of reluctance and require most careful scrutiny in admitting hearsay statements under its provisions." Ibid.) and by the Prefatory Note to the entire set of rules ("Of course a given rulc would be inoperative in a given situation when there would occur from its application an invasion of constitutional rights." Id. at 163.).

14. 5 WIGMORE, op. cit. supra note $5, \& 1420$.

15. Mattox v. United States, 146 U.S. 140, 152 (1892).

16. For an extensive analysis of how effectively hearsay rules deal with problems of narration, sincerity, memory and perception, see Morgan, supra note 5 . 
tute-fear of impending death-assures at most sincerity. ${ }^{17}$ And even if it gave some assurance of the other aspects of reliability, it would lack the unique potency of cross-examination. Only cross-examination subjects testimony to the ordeal of a hostile adversary's probe for weaknesses.

A second defect is equally crucial. Inevitably, any hearsay rule is arbitrary. The judge cannot halt the trial to ponder the reliability of every item of hearsay evidence; nor can attorneys calculate reliability in time to object to hearsay in a running narrative. They must have broad categories of admissibility which yield an effortless decision. In this area, rules of law must be rules of thumb. All we can ask is that the categories of admissible hearsay be generally reliable; any particular example may be suspect and call for the exercise by a trial judge of his discretion to exclude unreliable evidence.

In summary, no hearsay rule closely approximates the advantages of confrontation; and no rule accurately distinguishes between reliable and unreliable evidence. There are, no doubt, better and worse attempts. But experts cannot begin to sort them out; the empirical evidence is scanty and ambiguous. ${ }^{18}$ There is no basis for exalting any of these ragged approximations as the essence of the confrontation clause. The Court should not cast itself in this area, as it has in no others, as the final arbiter of the reliability of evidence.

When faced directly with problems of evidentiary weight, the Court has been wary. Its few forays into this swamp have been circumspect. Thompson v. City of Louisville ${ }^{10}$ and its progeny ${ }^{20}$ mark the outer limits. Petitioner in Thompson was arrested for loitering when police

17. The guarantee of sincerity seems the one most characteristic of the exceptions to the rule against hearsay. Morgan, supra note 5 at 203; Maguire, The Hearsay System: Around and Through the Thicket, 14 VAND. L. REv. 741, 749 (1961). Sce also Mrones. ConE OF EVDENCE $221-22$ (1912).

18. See, e.g., Hutchins and Slesinger, Some Observations on the Low of Eridence, Spontaneous Exclamations, 28 Colux. L. REv. 432 (1928). Paradoxically, the Court in Pointer chose one of the most vulnerable exceptions-dying declarations-as an example of an evidentiary category that meets constitutional standards. Sce note 9 supra. Of all the exceptions, the one for dying declarations has been called "the most mystical in its theory and the most arbitrary in its limitations." MfcCorarick, Eviderces $\$ 258$ (1954). The verbal product of a death agony would seem to be of dubious reliability.

19. 362 U.S. 199 (1960).

20. Shuttlesworth v. City of Birmingham, 382 U.S. 94 (1965); Garner v. Louisiana, 368 U.S. 157 (1961). Though Thompson is best known for establishing the principle that conviction may not be had on no evidence, its holding was foreshadowed in Schware $v$. Bd. of Bax Examiners, 353 U.S. 232 (1957). Rhetorically, however, the Court in Schure measured the sanity of bar examiners not the weight of evidence: "There is no evidence in the record which rationally justifies a finding that Schware was morally unfit to practice law." 353 U.S. at 246-47. 
entered a cafe and saw him shuffling his feet in time to background music. The arresting officers added a charge of disturbing the peace when petitioner became argumentative as they led him away. He was convicted of both charges in police court. Reversing, the Supreme Court said the question before it turned "not on the sufficiency of the evidence, but on whether this conviction rests upon any evidence at all."21 If any explanation of the case was necessary, the Court provided it in Shuttlesworth v. City of Birmingham: "The proposition for which that case stands is simple and clear. It has nothing to do with concepts relating to the weight or sufficiency of evidence in any particular case. It goes, rather, to the most basic concepts of due process of law."22

If the Court adds a hearsay rule to the Constitution, it will face the case-by-case review of evidence that it sidestepped in Thompson. Hearsay questions demand particularized judgment, and require as much familiarity with the record as with the rulebook. Only by sifting the evidence itself can the Court be sure that a particular use of hearsay is not harmless error or the exercise of trial court discretion. But no task could be further from the Supreme Court's constitutional function than the exercise of routine appellate review.

This is not to say that there is no room in the Constitution for a requirement of some measure of evidentiary reliability. But this requirement should be enforced through the due process clause, not the confrontation clause. ${ }^{23}$ As Thompson and its progeny illustrate, hearsay problems are not the only ones that arise in connection with criminal trial evidence. The potential for admitting worthless evidence is as broad as the range of facts that may be presented in a courtroom, either through testimonial or real proof. The confrontation clause, even if given the widest interpretation possible under Pointer, protects only against weaknesses in testimony that arise for want of cross-examination. Moreover, if there exists this basic and extensive concern with minimal reliability, it should not be confined to criminal cases as it would be under the confrontation clause. Only due process is pervasive enough to reach the evil.

The confrontation clause should serve a discrete and more limited function. It should focus on the legitimate concerns raised by a liberalized hearsay rule: that such a rule may institutionalize baseless prose-

21. 362 U.S. at 199.

22. 382 U.S. 87,94 (1965).

23. Compare Henkin, "Selective Incorporation" in the Fourteenth Amendment, 78 YALE L.J. 74 (1963). 
cutions, or at least tempt prosecutors to use hearsay instead of live witnesses whose demeanor is unimpressive; or that it may induce prosecutorial negligence in securing witnesses by holding out the easy alternative of presenting their statements through other witnesses. Such pratices undermine any system of criminal justice that presumes innocence and insists that the process of rebutting the presumption be absolutely above reproach.

Fears of this sort would be allayed by a confrontation clause read not as a Delphic reference to the essence of the hearsay rule, but as a canon of prosecutorial behavior. The clause should be held to require that the prosecutor make a diligent, good-faith effort to produce witnesses to testify. So read, the clause would bind the prosecutor regardless of whether some exception to the rule against hearsay would allow the prospective witness' testimony to be recounted by others.?

The objection to the prosecutor's presentation of hearsay instead of an available witness is not that such hearsay necessarily is less reliable than the hearsay of an unavailable witness, but that the prosecutor has made the testimony less reliable than it might have been. ${ }^{25}$

Although the Supreme Court never has discussed confrontation explicitly in terms of prosecutorial behavior, its decisions strongly suggest such a rule. Greene v. McElroy ${ }^{20}$ presents a striking example of objectionable failure by the government to present witnesses. ${ }^{2 \tau}$ Greene dealt with the dismissal of an executive of a private company that held defense contracts solely because his security clearance had been revoked by a Defense Department security board. The revocation came after a hearing at which the government presented no witnesses. "It was obvious, however . . . that the Board relied on confidential reports which were never made available to petitioner. . . Petitioner had no opportunity to confront and question persons whose statements reflected adversely on him or to confront the government investigators who took their statements." 28 The Court sidestepped the constitutional

24. For example, although an excited utterance is admissible under conventional hearsay rules, MCCORMICE, EVDENCE $\$ 272$ (1954), the prosecutor would be required under the proposed standard to produce an available witness.

25. Cf. Napue v. Illinois, 360 U.S. 264 (1959); Mooney v. Holohan, 294 U.S. 103 (1935).

26. 360 U.S. 474 (1959).

27. Though petitioner suffered no criminal sanction, the loss of his job and the damage to his reputation that followed the loss of security clearance apparently were sufficient to warrant application by the Court of criminal trial standards The goiernment's failure in Greene to present witnesses was not unique. Sec, e.g., Peters v. Hobby, 349 U.S. 331 (1955); Bailey v. Richardson 341 U.S. 918 (1951), affirming per curiam by an equally divided court 182 F.2d 46 (1950); Parker v. Lester, 227 F.2d 708 (9th Cir. 1955). Compare Dayton v. Dulles, 357 U.S. 144 (1958).

28. 360 U.S. at 479. 
question, holding that the Board was authorized by Congress and the President to conduct only the kind of security clearance program "which affords affected persons the safeguards of confrontation and cross-examination." 29

A confrontation clause incorporated into the Fourteenth Amendment speaks not only to the threat of Big Government foreshadowed by the Defense Department's Industrial Security Board, but also to the homespun guile and sloth of local prosecutors. The obligation of federal prosecutors to present at trial the best available evidence was estab. lished in leading decisions under the confrontation clause before Pointer extended it to the states. Petitioner in Kirby $v$. United States ${ }^{30}$ was charged with receiving stolen goods. The Court found error in the admission, to prove the property was stolen, of evidence that three other persons had been convicted of stealing it. In Motes $v$. United States, ${ }^{31}$ petitioner's conviction was reversed because the trial judge admitted a transcript of testimony taken at a preliminary hearing after a showing that the witness' absence was due to the prosecutor's negligence. In both cases the prosecutors settled for second-hand evidence. In neither was there a showing that first-hand evidence was unavailable.

Pointer and its companion case, Douglas $v$. Alabama, ${ }^{32}$ come within the compass of the earlier decisions. In Pointer the state where the trial was held and the state where the key witness had gone were signatories to the Uniform Act to Secure the Attendance of Witnesses from Without the State, ${ }^{33}$ which, in effect, allows interstate service of process. Since the victim's hearsay testimony was the most damaging piece of evidence against petitioner, it was reasonable to require that the prosecutor undergo the slight inconvenience of using the act to insure the witness' presence. There is no indication that he attempted to do so.

In Douglas the prosecutor knew in advance that a witness he intended to call, a confessed accomplice of the defendant who had been convicted at a separate trial, would avoid damaging his chances for an appeal by refusing on Fifth Amendment grounds to testify. Nonetheless, he was called. When he refused to testify, the prosecutor read aloud from his confession, which incriminated the defendant, pausing

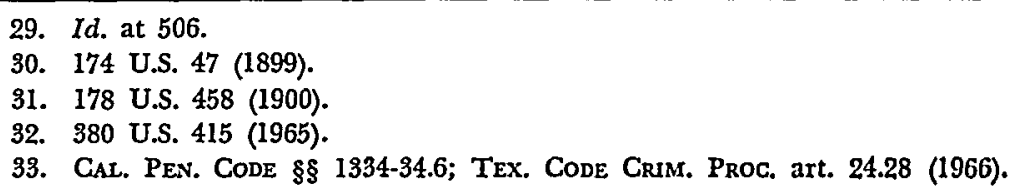

29. Id. at 506.

30. 174 U.S. 47 (1899).

31. 178 U.S. $458(1900)$.

32. 380 U.S. 415 (1965).

33. Cal. Pen. Code §§ 1334-34.6; Tex. Code Crum. Proc. art. 24.28 (1966). 
at intervals to inquire whether the witness remembered having made the statements attributed to him. The Court reversed the defendant's conviction.

It is arguable that however cynical the prosecutor's charade, he did present the best available evidence by bringing a live witness to the stand. When the witness refused to testify, he had no choice but to rely upon hearsay testimony. So read, Douglas would equate confrontation with the hearsay rule. But it was not simply the introduction of hearsay that disturbed the Court. The confession might have been admissible under conventional hearsay law as a declaration against penal interest, ${ }^{34}$ and in fact was described in the testimony of two policemen. The prosecutor, however, knowing in advance the witness would refuse to testify, called him simply to enhance the credibility of the confession by putting words in the witness' instead of the prosecutor's mouth; that is, to profit from the same illusion that for ages has made ventriloquism such an engaging folk art. It was this enhancement of credibility and not simply the presentation of hearsay that drew the Court's major objection. The Court distinguished between the prosecutor's reading and the witness' invocation of the Fifth Amendment. The former indicated only that the confession was made by the witness. This inference could be partially tested by cross-examining the two policemen who had testified that the confession was made. But the witness' reliance on the Fifth Amendment suggested that the confession implicating the defendant was true; that inference could not be tested because only the witness was competent to discuss it and he refused to testify. ${ }^{35}$

The cases in which the Court has denied claims based on the confrontation clause do not appear to involve violations of the proposed standard, and thus are consistent with it. ${ }^{30}$ This frees the Court to

34. See Uniform Rules OF EVIDENCE 63(10).

35. 380 U.S. at $419-20$. In Turner v. Louisiana, 379 U.S. 466 (1965), the Court reversed a conviction after the credibility of witnesses' testimony had been enhanced in a way that put it beyond attack by cross-examination. Two deputy sheriffs, important witnesses at a murder trial, had custody of the jury. "... [T] [Te relationship was one which could not but foster the jurors' confidence in those who were their official guardians during the entire period of the trial." Id. at 474. The case pre-dated Pointer and Douglas, however, and the due process standard was employed.

36. Snyder v. Massachusetts, 291 U.S. 97 (1934) (view by jury of crime scene held not to present confrontation problem); Dowdell v. United States, 221 U.S. 325 (1911) (judge, clerk and official reporter who certified that defendants had been arraigned and had pleaded in trial court not "witnesses" within the meaning of a statute embodying the constitutional standard.); Mattox v. United States, 156 U.S. 237 (1845) (cross-examined testimony of deceased witnesses held admissible). But of., Salinger v. United States, 272 
interpret the confrontation clause as a standard of prosecutorial behavior and to abandon the unwieldy and unwise hearsay-confrontation equation suggested by the rhetoric in Pointer.

U.S. 542 (1926) (letters from persons not called as witnesses admitted to explain replies by accused to them-perhaps a marginal case, though the most damaging evidence ap. pears to have come from letters written by the accused). 